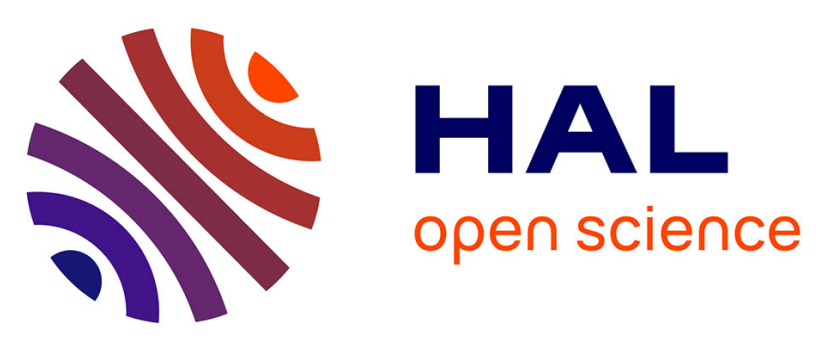

\title{
Design and multi-physical properties of a new hybrid hemp-flax composite material
}

\author{
J. Page, M. Sonebi, Sofiane Amziane
}

\section{To cite this version:}

J. Page, M. Sonebi, Sofiane Amziane. Design and multi-physical properties of a new hybrid hemp-flax composite material. Construction and Building Materials, 2017, 139, pp.502 - 512. 10.1016/j.conbuildmat.2016.12.037 . hal-01652368

\section{HAL Id: hal-01652368 \\ https://hal.science/hal-01652368}

Submitted on 28 Feb 2019

HAL is a multi-disciplinary open access archive for the deposit and dissemination of scientific research documents, whether they are published or not. The documents may come from teaching and research institutions in France or abroad, or from public or private research centers.
L'archive ouverte pluridisciplinaire HAL, est destinée au dépôt et à la diffusion de documents scientifiques de niveau recherche, publiés ou non, émanant des établissements d'enseignement et de recherche français ou étrangers, des laboratoires publics ou privés.

\section{다)(1) $(5$}

Distributed under a Creative Commons Attribution - NonCommerciall 4.0 International 


\section{国/ QUEEN'S UNIVERSITY BELFAST}

\section{Design and multi-physical properties of a new hybrid hemp-flax composite material}

Page, J., Sonebi, M., \& Amziane, S. (2017). Design and multi-physical properties of a new hybrid hemp-flax composite material. Construction and Building Materials, 139, 502-512. [1].

https://doi.org/10.1016/j.conbuildmat.2016.12.037

\section{Published in:}

Construction and Building Materials

\section{Document Version:}

Peer reviewed version

Queen's University Belfast - Research Portal:

Link to publication record in Queen's University Belfast Research Portal

\section{Publisher rights}

(C) 2016 Elsevier Ltd. This manuscript version is made available under the CC-BY-NC-ND 4.0 license http://creativecommons.org/licenses/bync-nd/4.0/ which permits distribution and reproduction for non-commercial purposes, provided the author and source are cited.

\section{General rights}

Copyright for the publications made accessible via the Queen's University Belfast Research Portal is retained by the author(s) and / or other copyright owners and it is a condition of accessing these publications that users recognise and abide by the legal requirements associated with these rights.

Take down policy

The Research Portal is Queen's institutional repository that provides access to Queen's research output. Every effort has been made to ensure that content in the Research Portal does not infringe any person's rights, or applicable UK laws. If you discover content in the Research Portal that you believe breaches copyright or violates any law, please contact openaccess@qub.ac.uk. 


\section{Design and multi-physical properties of a new 2 hybrid hemp-flax composite material}

3 J. Page ${ }^{\mathrm{a},},{ }^{,}$, M. Sonebi ${ }^{\mathrm{b}}$, S. Amziane ${ }^{\mathrm{c}}$

$4 \quad$ a ESITC Caen, 1 rue Pierre et Marie Curie, 14610 Epron, France

$5 \quad b$ School of Natural and Built Environment, Queen's University Belfast, University Road, Belfast BT7 1NN,

$6 \quad$ Northern Ireland, UK

$7 \quad$ c Institut Pascal, Clermont Université UMR 6602, 2 avenue Blaise Pascal, 63178 Aubière, France

8 *Corresponding author. E-mail address: jonathan.page@esitc-caen.fr (J. Page).

$9 \quad$ ARTICLE INFO

10 Keywords :

11 Hemp concrete

12 Flax fibers

13 Water absorption

14 Mechanical properties

15 Shrinkage

- The incorporation of the flax fibers has increased the ductility of the hemp concrete.

19 - Flax fibers have improved the compressive strength of hemp concrete.

20 - The hybrid composite appears to have a lower water absorption than hemp concrete.

- Hemp-flax hybrid concretes showed a lower shrinkage of about $15 \%$ compared to conventional hemp concrete. 
An experimental investigation was conducted in order to study the properties of a hybrid hempflax composite material in term of capillary water absorption, mechanical strength, thermal conductivity and shrinkage. The hemp-flax composite material is made with $90 \%$ hemp shives and $10 \%$ flax fibers. Hemp aggregates have a high water absorption capacity, which led to a reduction of the hemp concrete mechanical performances. Four mixes were made for: shuttered walls, external coating, floor insulation and roof insulation. Firstly, bio-based aggregates were characterized in term of particle size distribution and water absorption. Then, the compressive strength of these four mixes was determined to compare the mechanical behavior of the hybrid composite material with hemp concrete. The capillary absorption and the total shrinkage of these bio-based materials were also measured. Finally, we measured the thermal conductivity coefficient of these materials. The results of the compressive strength show a significant improvement due to the incorporation of flax fibers. Flax fibers improve the compactness of the material, thus increasing its density, which leads to a greater mechanical strength. It was observed that the capillary absorption of hemp concrete seems to be related to the aggregates/paste ratio. Finally, flax fibers have reduced hempcrete shrinkage of about 15\%. 


\section{Introduction}

Currently, the construction industry is responsible for $24 \%$ of carbon dioxide emissions and $44 \%$ of the energy consumption in France [1]. New building insulation standards tend to decrease the amount of energy used for heating, which accounts for almost two thirds of the energy consumption and the main part of the $\mathrm{CO}_{2}$ emissions in the building sector in France. However, in this context, energy expenditure devoted to the manufacture and the implementation of construction materials is increasing. Regarding France's commitments to the Kyoto protocol for 2050, the development of new materials based on renewable resources is necessary.

Plants have been largely forgotten by modern technologies. The evolution of production processes, the need for materials compatible with sustainable construction, consumer expectations and regulatory requirements mean that bio-based materials are becoming increasingly interesting. Among the plants usable for construction, hemp certainly has a privileged position and can be considered as a model. Hemp stands out because of its environmental assets such as its contribution to the improvement of the soil, its neutral carbon accounting, its low embodied energy expenditure and its end of life without harmful consequences for the environment [2]. From hemp is extracted shiv, which is mostly used as litter for animals thanks to its absorbent properties [3]. However, hemp shiv can be mixed with binders (lime and/or cement) and water to make hemp concrete.

Hemp-lime concrete is used only for twenty years in construction in France. It is most frequently used in lining or filling to form a construction element having good thermal and sound insulation without structural contribution. For ten years, many researches have been conducted on this material, which now allows a better understanding of its properties [4]. Most published researches are focused on its acoustical, thermal and hygrothermal properties which result from the highly porous structure of hemp shiv [5-8]. Hemp concrete is a lightweight composite insulating material having a dry density ranging from 200 to $800 \mathrm{~kg} \cdot \mathrm{m}^{-3}$ [9]. This low density gives to hempcrete its high thermal properties. Indeed, its dry thermal conductivity is between 0.06 and $0.12 \mathrm{~W} \cdot \mathrm{m}^{-1} \cdot \mathrm{K}^{-1}$, depending on mix formulations. However, this porous structure also resulted in low strength and low rigidity of the material after curing. Generally, in most studies, hemp concrete compressive strength remained relatively low compared to other conventional building materials, often less than $1 \mathrm{MPa}$ [10-14]. 
However, a comparative study realized in 10 different laboratories, on identical hemp concrete formulations, showed that this material has an accurate repeatability regarding the density and the mechanical strength [15].

Given this low mechanical strength, hemp concrete cannot therefore be used as a load bearing material. This material is also characterized by an important mechanical ductility, with a compressive strain higher than $10 \%$ [10]. The literature suggests that the high absorption capacity of lignocellulosic aggregates, sometimes greater than $300 \%$ by mass, is one of the main causes of hemp concrete low mechanical performances [16]. It induces a decrease of the water available for the binder setting, which leads to poor binder-aggregate interface.

Hemp concrete is often directly implemented on the construction site, or manually into forms or by projection process [12]. These methods of implementation do not allow reaching a sufficiently high compactness. However, previous work has shown that the compaction of hemp concrete at fresh state led to an increase of the mechanical performances $[17,18]$. Hemp aggregates have a particle size distribution predominantly between 1 and $5 \mathrm{~mm}$ [19]. Flax fibers have diameters around 5 to 80 microns [20]. Flax fibers can therefore be inserted between hemp aggregates and thus increase the compactness of the composite. In addition, the flax fibers can help to improve the behavior of the hemp concrete in large strains and thereby increase its ductility [21].

This experimental work aims to study the effect of incorporating flax fibers on the performances of lime-hemp composite. For this purpose, the physical, mechanical and thermal properties of the hybrid hemp-flax composite were studied and compared to conventional hemp concrete. First of all, the water absorption flax fibers and hemp shives was measured. Then, the particle size distribution of hemp shiv was determined by image analysis. Four formulations were made to study the properties of these biobased composites. These formulations were based on the French professional execution rules for hemp concrete, published in 2012 [22]. These standard practices provide four hemp-lime concrete mix designs for four different applications: external coating, shuttered wall, floor insulation and roof insulation. Thus, through these four formulations, hybrid hemp- flax composite properties were measured and compared to conventional hemp concretes. 


\section{Materials and methods}

\subsection{Raw materials}

\subsubsection{Hemp aggregates and flax fibers}

Hemp shiv used as aggregates for this study was Tradical ${ }^{\circledR}$ HF. It is a hemp aggregate made from the inner woody core of the hemp plant's stem. Hemp is chopped, graded and de-dusted to give a natural, sound and breathable product. This type of shiv is compatible with lime-based binders and is marketed for individual housing construction in hemp concrete. Its absolute density, obtained with a gaz pycnometer, is equal to 1.48 . Hemp shiv is characterized by its low bulk density [23], about 110 kg.m ${ }^{-3}$, which additionally gives it a very low thermal conductivity of approximately $0.048 \mathrm{~W} \cdot \mathrm{m}^{-1} \cdot \mathrm{K}^{-1}$, determined with the transient hot-wire method [24].

Elementary flax fibers used for this work have a length of $12.7 \mathrm{~mm}$, with a diameter ranged between 43 and 53 microns and were grown in Italy. For this work, only untreated fibers were used. Monofilament flax fibers are used to improve cohesion, holding, mold-ability, and to limit the cracking of cementitious composites.

\subsubsection{Mineral binder}

The binder used in this study was Tradical ${ }^{\circledR}$ PF70. It has already used in several other researches for making hemp concrete $[2,6,18,25]$. It is a special lime binder based on aerial lime $(75 \%)$, hydraulic binder (15\%) and pozzolanic binder (10\%).

This binder has been chosen for its great capacity to generate carbonation reactions. Indeed, aerial lime contains a large amount of calcium hydroxide $\mathrm{Ca}(\mathrm{OH})_{2}$ [16]. Once mixed with water and aggregates and in the presence of carbon dioxide, carbonation of the lime takes place, converting calcium hydroxide into calcium carbonate $\left(\mathrm{CaCO}_{3}\right)$. This is a very slow reaction. It starts mainly when lime has sufficiently dried and can last for months or even years. Then, the hydraulic binder $(15 \%$ of the composition) allows a higher reactivity and better short term resistance. Indeed, dicalcium and tricalcium silicates present in the binder will react with water to form calcium silicate hydrates (C-S- 
$121 \mathrm{H}$ ) and portlandite. Finally, the pozzolanic binder (10\% of the composition) will react with calcium 122 hydroxide $\mathrm{Ca}(\mathrm{OH})_{2}$ during the cement hydration and will promote the formation of calcium silicate 123 hydrates [16].

\section{2.2. Methodology}

\subsubsection{Mix design}

126 According to the French professional execution rules for hemp concrete structures [22], four 127 different mixtures were used throughout this work:

- Mix C: external Coating.

- Mix W: shuttered Walls.

- Mix F: Floor insulation.

- Mix R: Roof insulation.

Amziane and Arnaud provide dosages based on experience for these four applications [9]. Mix 133 proportions by mass and notations used are presented in Table 1.

134 Two different concrete families have been formulated for this study. The first is a conventional 135 hemp concrete, wherein all the introduced aggregates are hemp shives. This concrete will be noted 136 later HC for Hemp Concrete. In the second hemp concrete, $90 \%$ (in mass) of the aggregates are hemp 137 shives and the remaining $10 \%$ are flax fibers. Hemp shives are therefore substituted partially $(10 \%$ in mass) by flax fibers. This second composite will be abbreviated FHC for Flax-Hemp Concrete.

Table 1. Composition in dry mass of each mixes for a batch of $1000 \mathrm{~g}$.

\begin{tabular}{|c|c|c|c|c|c|c|c|}
\hline & & \multicolumn{2}{|l|}{ Aggregates } & \multirow[t]{2}{*}{ Binder } & \multirow[t]{2}{*}{ Water } & \multirow{2}{*}{$\begin{array}{l}\mathrm{A} / \mathrm{W} \\
\text { mass ratio }\end{array}$} & \multirow{2}{*}{$\begin{array}{l}A / B \\
\text { mass ratio }\end{array}$} \\
\hline & & Hemp shiv & Flax fibers & & & & \\
\hline \multirow[t]{2}{*}{ Mix C } & $\mathrm{HC}$ & $170 \mathrm{~g}$ & - & $360 \mathrm{~g}$ & $470 \mathrm{~g}$ & 0.36 & 0.47 \\
\hline & FHC & $153 \mathrm{~g}$ & $17 \mathrm{~g}$ & & & & \\
\hline \multirow[t]{2}{*}{ Mix W } & $\mathrm{HC}$ & $230 \mathrm{~g}$ & - & $310 \mathrm{~g}$ & $460 \mathrm{~g}$ & 0.50 & 0.74 \\
\hline & FHC & $207 \mathrm{~g}$ & $23 \mathrm{~g}$ & & & & \\
\hline Mix F & $\mathrm{HC}$ & $220 \mathrm{~g}$ & - & $410 \mathrm{~g}$ & $370 \mathrm{~g}$ & 0.59 & 0.54 \\
\hline
\end{tabular}




\begin{tabular}{llllllll} 
& FHC & $198 \mathrm{~g}$ & $22 \mathrm{~g}$ & & & & \\
Mix R & HC & $320 \mathrm{~g}$ & - & $220 \mathrm{~g}$ & $460 \mathrm{~g}$ & 0.70 & 1.45 \\
& FHC & $288 \mathrm{~g}$ & $32 \mathrm{~g}$ & & & \\
\hline
\end{tabular}

140

141

142

143

144

145

146

147

148

149

150

151

152

153

154

155

156

157

158

159

\subsubsection{Mixing procedure}

One of the main difficulties encountered during the hemp concrete mixing is due to the water absorption of plant aggregates. This water absorption creates a problem for the binder which needs to be hydrated [18]. For this reason, it is essential to take into account the water absorption capacity of the raw natural particles. Thus, hemp shives and flax fibers were first pre-wetted in the mixing drum during 2 minutes with $65 \%$ of the water quantity. Then, the binder was added and mixed during 1 minute. Finally the remaining water (35\%) was introduced in the mixing drum and mixed during 2 minutes. The total mixing time was equal to 5 minutes.

\subsubsection{Casting procedure and curing conditions}

The concrete was poured in the different molds: $50 \times 50 \times 50 \mathrm{~mm}^{2}$ cubs for compressive test and $100 \times 100 \times 100 \mathrm{~mm}^{2}$ cubs for capillary water absorption measurement. They were compacted in three layers by using a steel manual device (Fig. 1). The height of a single layer is equal to one-third of the total height of the concrete specimen (50 or $100 \mathrm{~mm}$ ). The first and second layers have been scratched to obtain a good grip surface for the next layer. Specimens were demolded after $24 \mathrm{~h}$ and stored in a climate-controlled room at $20^{\circ} \mathrm{C}$ and $60 \% \mathrm{RH}$.

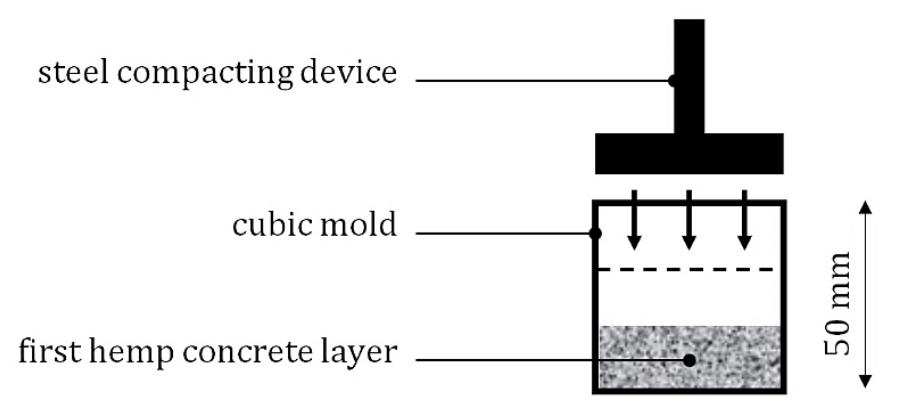

The shrinkage was measured on prism of $50 \times 50 \times 200 \mathrm{~mm}$. A shrinkage measurement device has been used, so it was necessary to place a metallic ball on both ends of each specimen. To place these balls, a hole was dug at each end of the specimens after release. Then, a quick-setting mortar has been 

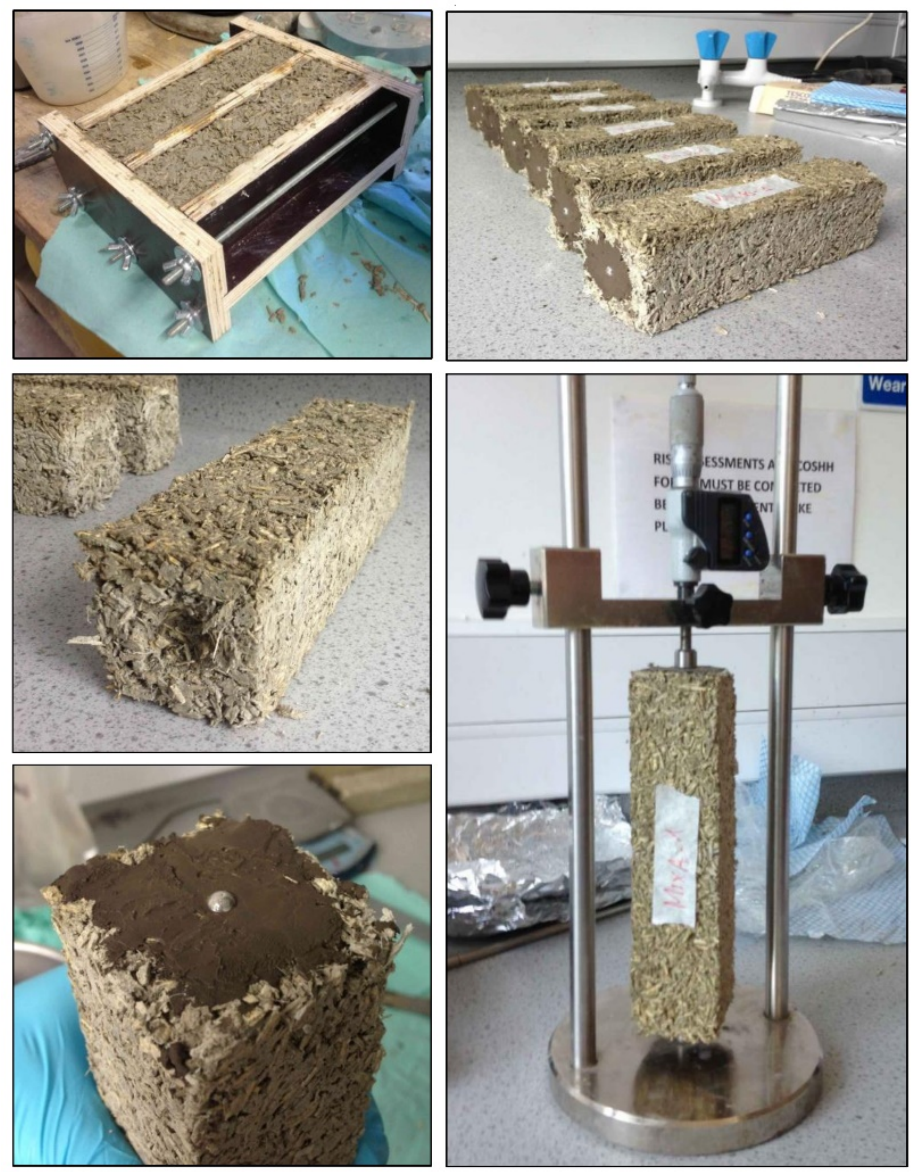

Fig. 2. Prisms manufacturing and shrinkage measurement.

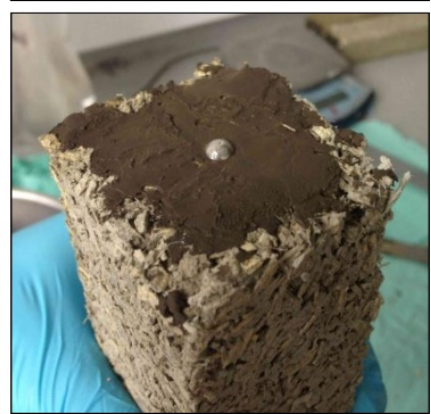

\subsubsection{Hemp shiv particle size distribution by image analysis}

Previous studies have shown that image analysis is the most efficient method to characterize the particle size distribution of hemp shiv $[16,17]$. Indeed, because of the elongated shape of hemp particles, the particle size distribution by mechanical sieving is inappropriate [26]. In order to compare the results with image analysis, a particle size by sieving of hemp shiv has nonetheless been achieved according to EN 933-2 [27]. This method of characterization is recommended by the RILEM Technical 
fitting ellipse" to calculate morphological parameters, such as the major and minor axes (
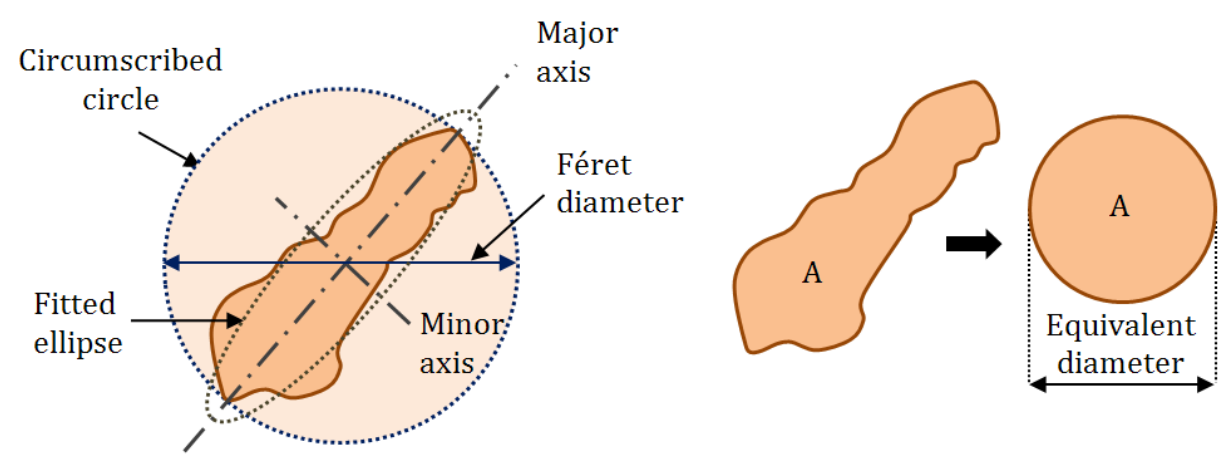

Fig. 3).

The main advantage of this method compared to sieve grading is to obtain a characterization of complex particle morphology and heterogeneity. Nevertheless, this technique is limited to small aggregate quantities (some grams) and hemp hurd residual fibers cannot be detected. Three different random samples of at least 2000 particles were placed on a black sheet of paper. Then the digital acquisition is treated with the image processing software. The morphological parameters selected for analysis are the following:

- Major axis dimension (major): length of the longest axis of the fitted ellipse.

- Minor axis dimension (minor): length of the shortest axis of the fitted ellipse (perpendicular to the major axis).

- Particle area (A): area of the aggregate, measured by the number of pixels.

- Particle perimeter (P): contour of the particle in pixels.

- Equivalent diameter (ED): the diameter of a circle having the same area as the object, defined as:

$$
E D=\sqrt{\frac{4 * A}{\pi}}
$$
than 1. 

calculated as follows:

$$
\text { Circularity }=4 \pi * \frac{\mathrm{A}}{\mathrm{P}}
$$

192
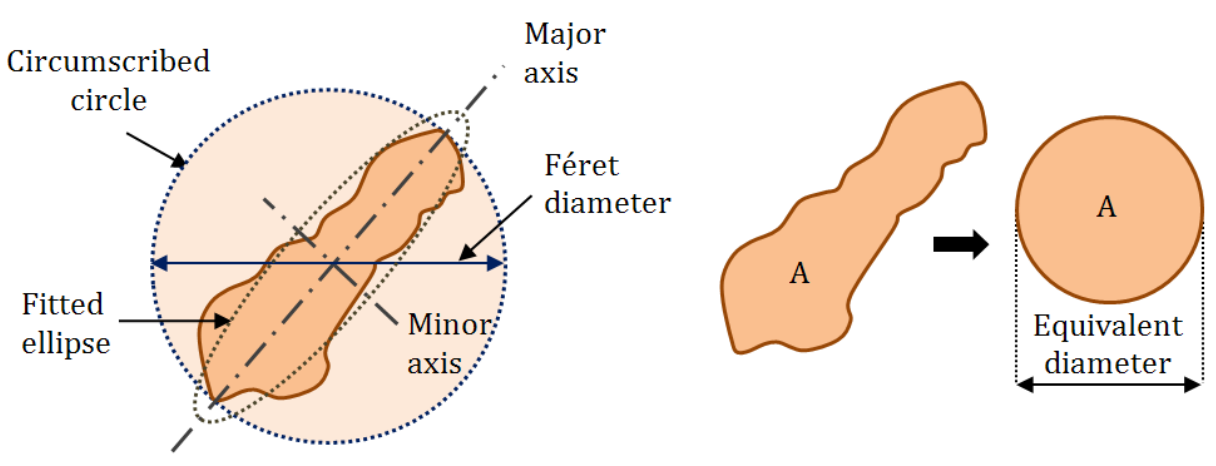

Fig. 3. Definition of calculated geometric parameters.

\subsubsection{Plant particles water absorption}

Due to their porous structure, hemp shiv and flax fibers are very sensitive to water $[10,28]$. The protocol used to measure water absorption is as follows [29,30]:

1. Dry 200 grams of aggregates at $60^{\circ} \mathrm{C}$ up to $\pm 0.1 \%$ mass variation in 24 hours is achieved.

2. Put a synthetic or metallic bag (with holes around $1 \mathrm{~mm}^{2}$ ) in water for a complete wetting.

3. Put the bag in a salad spinner and turn it 100 times at approximately 2 rotations per second.

4. Tare the spinned bag and note the value.

5. Weight 25 grams $\left(\mathrm{M}_{0}\right)$ of dry aggregate and put it in the water permeable bag.

6. Put the bag of aggregates in water for 1 minute.

7. Put this bag in a salad spinner and turn it 100 times at approximately 2 rotations per second.

8. Weight the spinned aggregates bag and note the $\mathrm{M}_{1}$ value (1 min).

9. Repeat steps 6, 7 and 8 with another the sample at different times: 15, 240 and 2880 minutes. 


$$
M(t)=\frac{M_{t}-M_{0}}{M_{0}} * 100
$$

The water absorption has been measured on hemp shiv and on flax fibers. In order to see the repeatability, this test was carried out three times for each aggregate. This method of characterization is recommended by the RILEM Technical Committee 236-BBM [31].

\subsubsection{Compressive tests}

Compression tests were performed after 7 and 28 days of curing in a climate-controlled room $(20$ ${ }^{\circ} \mathrm{C}$ and $60 \% \mathrm{RH}$ ) by using an electromechanical testing machine with a $50 \mathrm{kN}$ capacity. They were conducted on $50 \times 50 \times 50 \mathrm{~mm}$ cubes with a $3 \mathrm{~mm} \cdot \mathrm{min}^{-1}$ speed. Three replications were done for each mix.

\subsubsection{Capillary water absorption}

Capillary water absorption was measured after 7 days of curing in a climate-controlled room $\left(20^{\circ} \mathrm{C}\right.$ and $60 \% \mathrm{RH}$ ) by using a cube of $100 \mathrm{~mm}$ size. Then, the specimens were dried during $24 \mathrm{~h}$ before testing. Two replications were done for each mix.

The purpose of this test is to simulate a capillary rising in a masonry wall, in order to assess the concrete behavior towards water. A waterproof tape was applied around the circumference of the test piece. Test pieces were then placed in a plastic container on two steel bars (to ensure water absorption only on the underside of the specimen). Finally, the container was filled with water until obtain an imbibition front of $8 \mathrm{~mm}$. Water level was maintained to $8 \mathrm{~mm}$ during the time of the experiment (Fig. 4).

The specimens initial dry mass is first measured $\left(\mathrm{M}_{0}\right)$. Then, the specimens were weighed after different time of immersion in water $\left(\mathrm{M}_{\mathrm{t}}\right)$. The Eq. 3 has been used to calculate the capillary water absorption. 


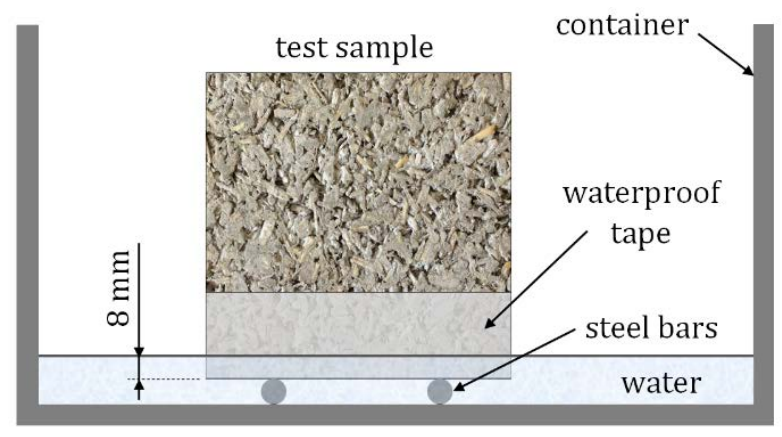

Fig. 4. Measuring system of capillary water absorption.

\section{0}

\subsubsection{Shrinkage measurement}

Two samples of each mix were tested using French cement standard NF P15-433 [32]. The specimens were stored in a climate-controlled room $\left(20^{\circ} \mathrm{C}\right.$ and $\left.60 \% \mathrm{RH}\right)$ during all the measurement of the total shrinkage. Measurements were made using a shrinkage apparatus having an accuracy of $0.001 \mathrm{~mm}$ and performed every 2-4 days up to 46 days (Fig. 2).

\subsubsection{Thermal conductivity}

Thermal conductivity of $\mathrm{HC}$ and FHC specimens was measured with a thermal apparatus (conductivimeter) using the transient hot-wire method, according to EN ISO 8894 [33] . This method consists in generating a heat flow by Joule effect and measuring the temperature variation over time by means of a thermocouple. This thermocouple is associated with the heating element in the hot-wire probe. The rise in temperature measured by the sensor is limited to $20^{\circ} \mathrm{C}$ and the measuring time is dependent on the material, here taken as 60 seconds. The temperature variation $(\Delta T)$ is related to the electrical power (P), the wire length (L) and the thermal conductivity $(\lambda)$ [34]. If the temperature is measured at times $t_{1}$ and $t_{2}$, the thermal conductivity is given by the following equation:

$$
\lambda=\frac{P}{4 \cdot \pi \cdot L \cdot \Delta T} * \ln \left(\frac{t_{2}}{t_{1}}\right)
$$




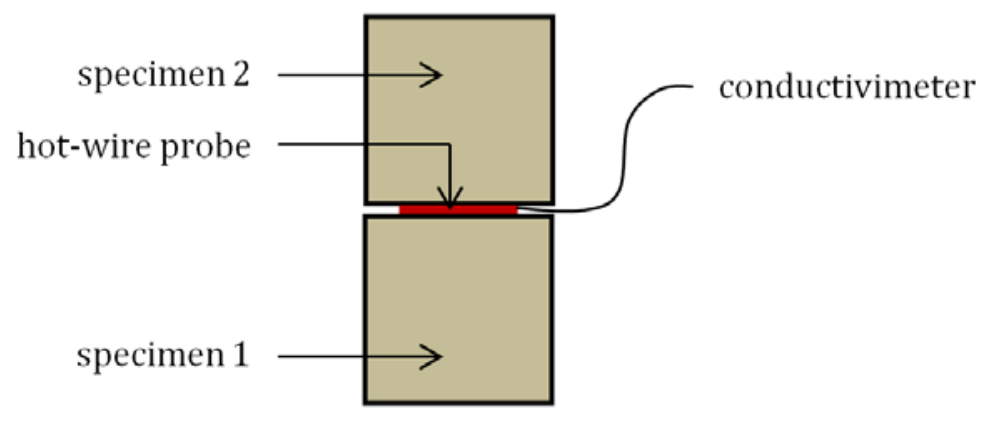

Fig. 5. Thermal conductivity measurement by the transient hot-wire method.

\section{Results and discussion}

\subsection{Plant particles characterization}

\subsubsection{Particle size distribution}

The particle size by sieving is the reference standard for characterizing mineral aggregates [27]. For lignocellulosic shives, the square mesh sieves are inadequate because they do not take into account the elongation of aggregates [26]. In Fig. 6, the particle size distribution of the shives produced by mechanical sieving is between 0.5 and $5 \mathrm{~mm}$. The particle length seems unlikely to change. Only the thickness and width of the particle condition the passage from one sieve to another.

Image analysis provides considerably more exhaustive information than the mechanical sieving. Fig. 6 reveals, in contrast to sieving, significant differences between the major and minor axes and the equivalent diameter. The median equivalent diameter is equal to $4.86 \mathrm{~mm}$ and the gap between the median $\mathrm{D}(\mathrm{a}, 0.5)$ of the minor and major axes equal to $7.49 \mathrm{~mm}$. At first sight, this reflects a great heterogeneity of the hemp aggregate. However, these values are consistent with the literature. Chabannes, for example, has found for its hemp shiv, an equivalent diameter of about $5 \mathrm{~mm}$ and a gap between the median of the minor and major axis approximately equal to $6.8 \mathrm{~mm}$ [35]. Nozahic, for its part, find for these two parameters, values equal respectively to $4.2 \mathrm{~mm}$ and $6.2 \mathrm{~mm}$ [36]. 


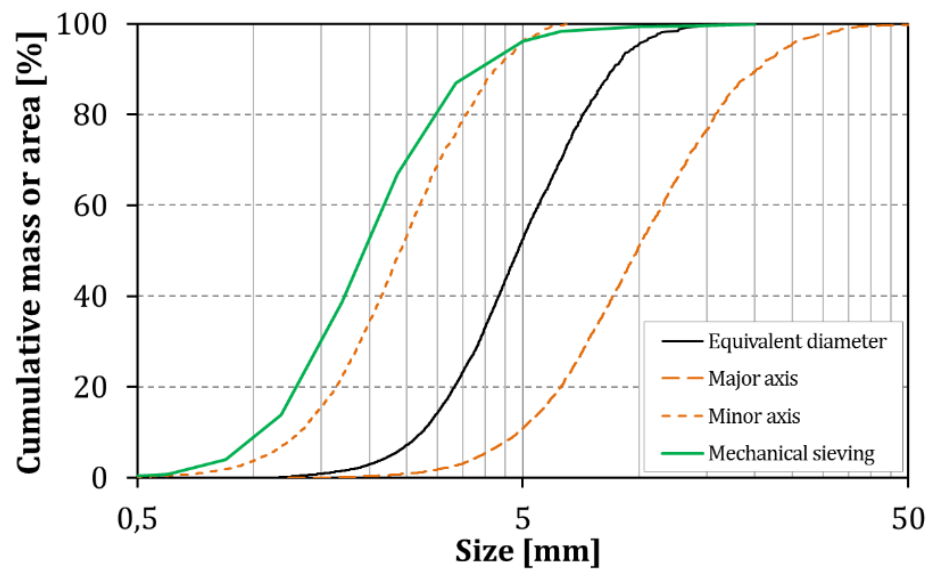

Fig. 6. Hemp shiv particle size curves obtained by image analysis and mechanical sieving.

The parameters derived from the image analysis are used to express other morphological criteria such as elongation and circularity (Fig. 7).

The elongation corresponds here to the calculated ratio between the dimension of the two axes of the ellipse (major axis / minor axis). The elongation follows a lognormal distribution. One hemp shiv population is present and which may have an elongation of up to 8 or more. The median value of the 272 elongation ratio is $3.82 \pm 2.33$. Generally, elongation is very high, which does not favor the granular particle arrangement. ratio is very low, about $0.26 \pm 0.14$. This confirms the high elongation of hemp aggregates.
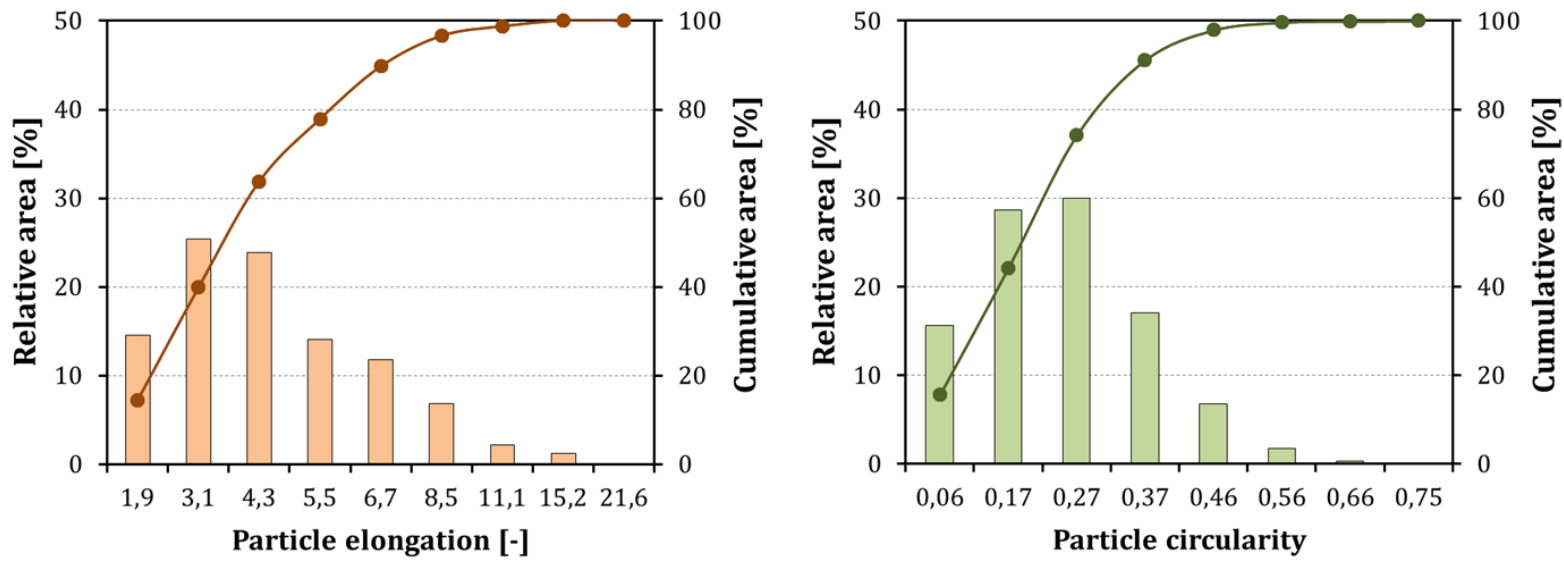

Fig. 7. Hemp shiv particle elongation and circularity. 


\subsubsection{Water absorption}

279

The absorption kinetics, measured by sequential weighing after immersion in water, is similar for both aggregates (Fig. 8). The water absorption is very fast to these two particles. These dry aggregates absorb more than a third of their maximum absorption capacity in less than a minute. The measured water absorption values are consistent with the literature $[14,16,28]$. The water absorption measured after 48 hours of immersion is about $450 \%$ for hemp and over $200 \%$ for flax fibers. The difference in the amount of water absorbed between hemp shiv and flax fibers can be explained by a lower hydrophilicity of the fibers, due to a less porous structure compared to hemp shives [9].

Two phases of absorption can be observed. The first one is a surface absorption phase which causes an almost instantaneous increase of the aggregate mass. It highlights the rapid nature of the wetting of hemp and flax particles. The second phase is the slow absorption into the vegetable structure. This demonstrates the diffusive behavior of the water propagation in the structure up to 48 hours. The wetting phase may be considered completed after 1 minute. The initial absorption $\mathrm{W}_{0}$ was set for this duration. On this value, an important difference is visible between hemp $\left(\mathrm{W}_{0}=181 \%\right)$ and flax $\left(\mathrm{W}_{0}=\right.$ $84 \%)$.

It is visible in Fig. 8 that the intra-granular water absorption follows a logarithmic law. Nozahic has defined the following relationship is valid until saturation aggregates [36]:

$$
\mathrm{W}(\mathrm{t})=\mathrm{C}_{\mathrm{A}} * \log (\mathrm{t})+\mathrm{W}_{0}
$$

- $\mathrm{W}_{0}$ : Initial water absorbed by the particles (1 min) ;

- $\mathrm{C}_{\mathrm{A}}$ : Water absorption coefficient of particles.

The water absorption capacity of bio-aggregates has a significant role in the formulation and implementation of hemp concrete. This hydrophilic property of vegetable particles influences the binder setting [18]. Indeed, hemp shiv and binder will be in competition to mobilize water, thereby altering the binder hydration. 


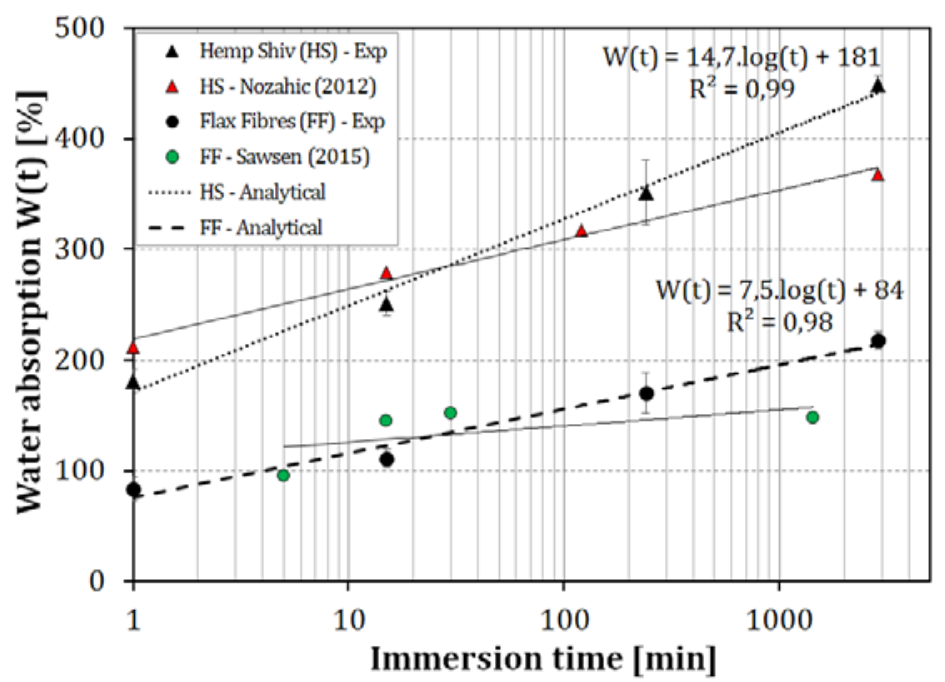

Fig. 8. Water absorption of hemp shives and flax fibers.

\subsubsection{Bulk density}

Fig. 9 presents the bulk densities obtained for $\mathrm{HC}$ and FHC after 28 days curing. It ranges from 250 to $500 \mathrm{~kg} \cdot \mathrm{m}^{-3}$, depending on mix formulation. The hemp concrete density is lower than ordinary concrete. It is this low density, which gives to hemp concrete its good thermal properties. Substituting $10 \%$ of the mass of hemp shives by an identical mass of flax fibers significantly affects the density of the material. Indeed, the density increased from $10.3 \%$ to $40.4 \%$ depending on the formulation.

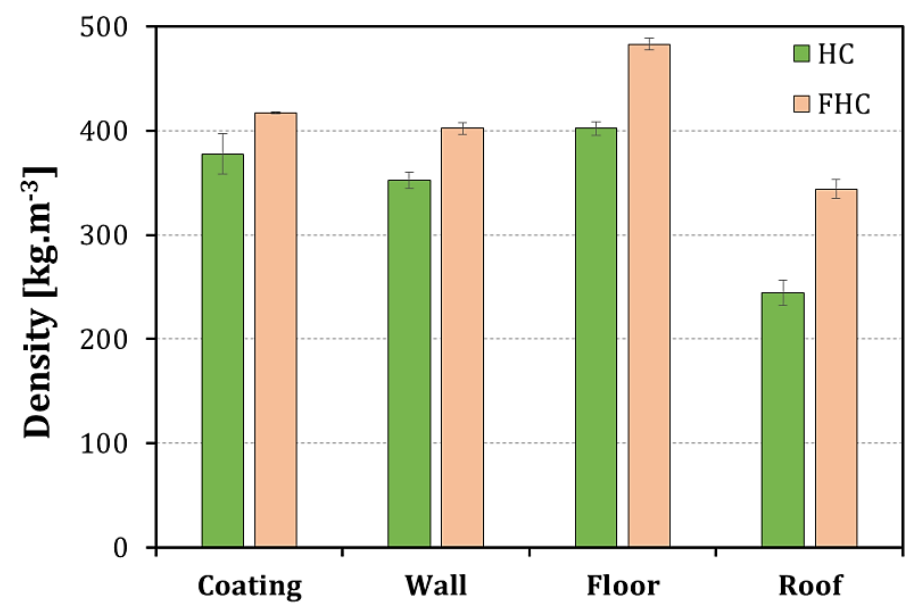

Fig. 9. Densities of HC and FHC after 28 days curing. 
In Fig. 10, it can be observed the density increased between $\mathrm{HC}$ and FHC concretes according to the A/W mass ratio. The density of hybrid hemp-flax concretes increased with $\mathrm{A} / \mathrm{W}$ ratio and the trend follows a quadratic polynomial function. The coefficient of determination was very close to 1 . In fact, the more the amount of hemp shives increases, the higher intergranular space is. Flax fibres, which have diameters smaller than hemp shiv, are insertable into these spaces, thereby led to an increase in the compactness. Hence a higher density for hybrid cementitious composites is obtained.

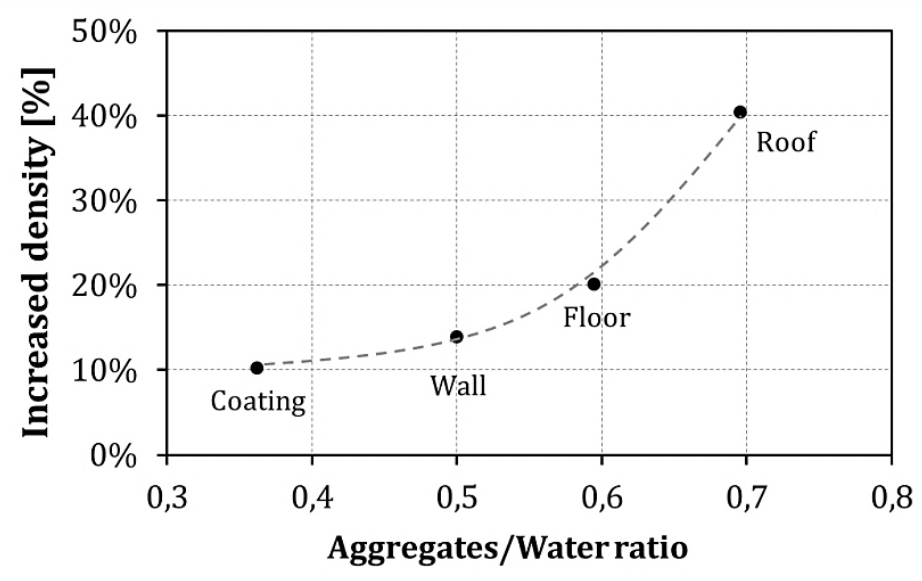

Fig. 10. Increased density between $\mathrm{HC}$ and $\mathrm{FHC}$ depending on the $\mathrm{A} / \mathrm{W}$ ratio.

\subsubsection{Capillary absorption}

Sonebi highlighted that hemp concrete is sensitive to weathering and in particular to wettingdrying cycles [37]. He noted a decrease of the mechanical strength from 50 to $80 \%$ after 10 wettingdrying cycles, according to the formulations. Therefore the water absorption of hemp concretes is an important parameter for the durability of this material.

Capillary water absorption can be used as an indicator of the degradation of building materials, especially for masonry blocks. It can be described by the water absorption coefficient. The latter results from the gradient of the straight line of curves presented in Fig. 11 as the mass of water absorbed versus square root of time. This capillary water absorption coefficient is defined as $C_{A}\left(\mathrm{~kg} \cdot \mathrm{m}^{-2} \cdot \mathrm{h}^{-1 / 2}\right)$ by the following equation:

$$
\mathrm{M}_{\mathrm{w}}=\mathrm{C}_{\mathrm{A}} * \sqrt{\mathrm{t}}+\mathrm{k}
$$


- $\mathrm{k}$ is a function of the contact area with water $\left(\mathrm{kg} \cdot \mathrm{m}^{-2}\right)$ corresponding to the $\mathrm{y}$-intercept of the straight line ;

- $\sqrt{\mathrm{t}}$ is the square root of time.

As it can be seen from the results on Fig. 11, the capillary kinetics is similar for the different composites. Water absorption is initially increasing, then slows down as time progresses. However, there is a significant difference in the rate at which capillary water is absorbed.

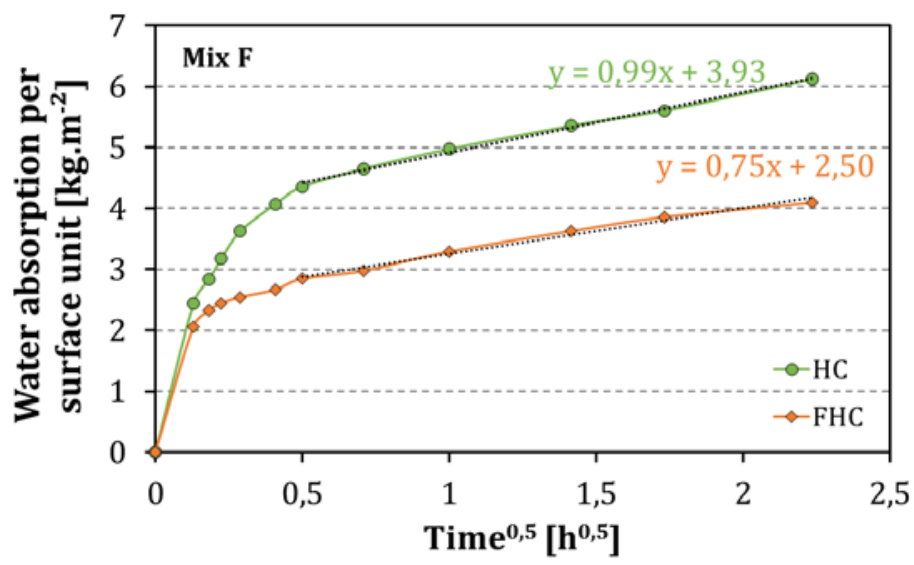

Fig. 11. Capillary water absorption curves for floor insulation mixture specimens (Mix F).

The water absorption coefficients are represented in (Fig. 12). They range from 0.81 to $2.52 \mathrm{~kg} . \mathrm{m}^{-}$ ${ }^{2} \cdot \mathrm{h}^{-1 / 2}$. These values are lower than those observed by Walker [8] (between 2.65 and $3.37 \mathrm{~kg} \cdot \mathrm{m}^{-2} \cdot \mathrm{h}^{-1 / 2}$ ). 340 This can be explained by a measurement of the capillary absorption after only 7 days curing. In addition, the imbibition height used by Walker was different (10 $\mathrm{mm})$.

The addition of $10 \%$ flax fibres seems to decrease capillary absorption of hemp concrete for mixtures containing a low proportion of vegetable aggregates. Indeed, the $\mathrm{C}_{\mathrm{A}}$ coefficient is lower for mixes $\mathrm{C}$ and

344 F. In contrast, the absorption coefficient increased for mixtures containing a higher proportion of hemp, i.e. mixtures $\mathrm{W}$ and $\mathrm{R}$. 


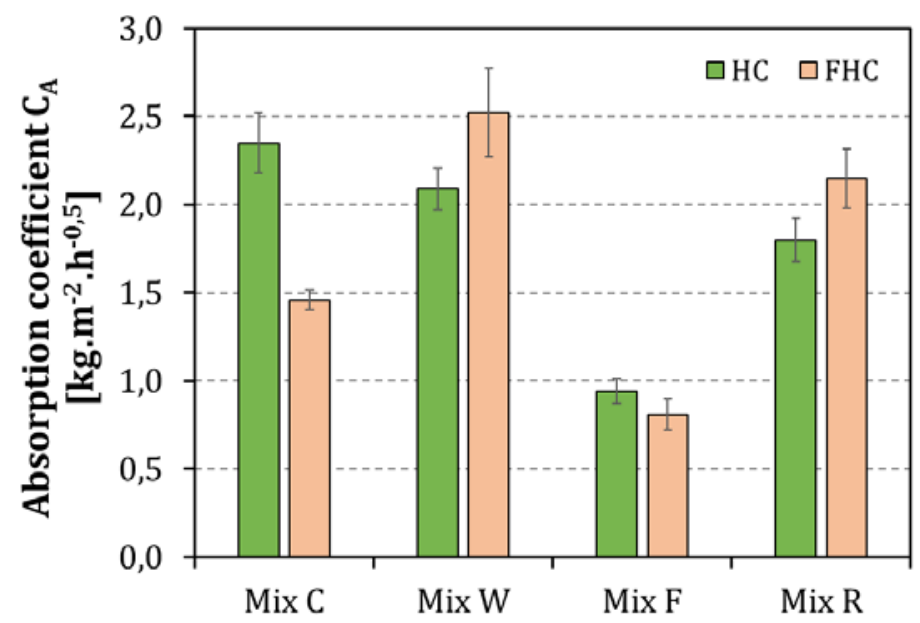

Fig. 12. Absorption coefficients for $\mathrm{HC}$ and FHC.

Capillary porosity is defined as residual spaces occupied by the original kneading water. Indeed, some studies show that the capillary water absorption of hemp concrete depends on the amount on aggregates [38]. These same results are obtained with the HC (Fig. 13). The more important the aggregates/paste ratio is, the more the maximal capillary water absorption (after 5 hours) increases.

352 In fact, this ratio is known to affect the relative volume of solids and capillary voids. The volume of capillary voids increases with the aggregates amount and the capillary water absorption is strongly linked to capillary voids.

However, the relationship between the aggregates/paste ratio and capillary absorption cannot be seen with FHC hybrid concrete. This could be due to an increase of tortuosity of the concrete pore structure due to the presence of flax fibers, which would complicate the capillary suction phenomenon and so the quantity of water absorbed (Fig. 13).

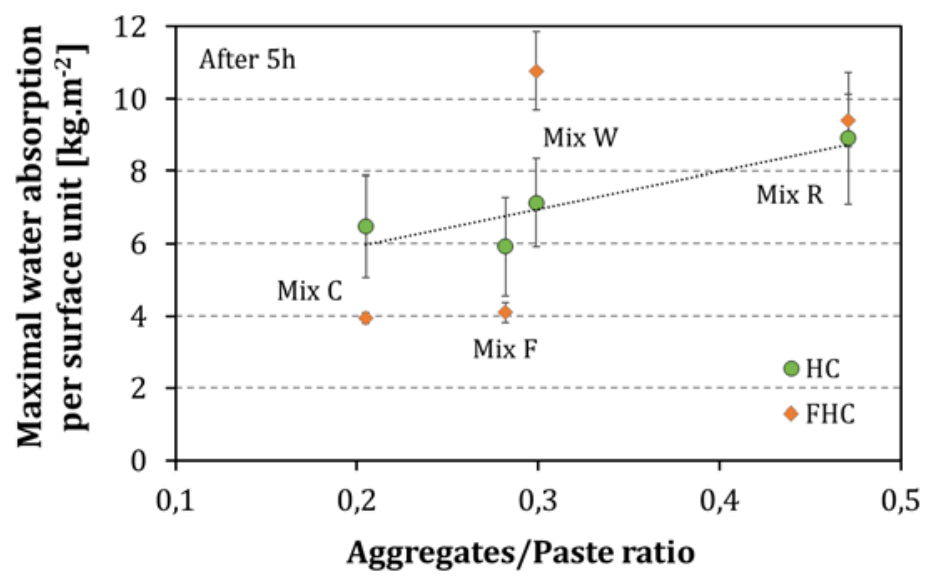


Fig. 13. Maximal water absorption per surface unit according to the aggregates/paste ratio.

361

362

363

\subsubsection{Shrinkage}

The phenomenon has not been widely investigated for lime and hemp shiv concretes. However, Murphy and Kashtanjeva studied hemp concrete shrinkage [39,40]. A similar behavior is obtained with hemp concrete, reinforced with flax fibers or not (Fig. 14). The increase of the shrinkage was relatively constant up to 25 days. Then the shrinkage continued to increase slowly until the end of the test to 46 days (Fig. 14). The shrinkage stabilised for $\mathrm{HC}$ concrete after 25 days, at $8.5 \mathrm{~mm} . \mathrm{m}^{-1}$ for mix W (shuttered wall) and about $4.5 \mathrm{~mm} . \mathrm{m}^{-1}$ for mix C (external coating). For both mixes, hybrid hemp-flax concrete has a lower shrinkage of about $15 \%\left(7.5 \mathrm{~mm} \cdot \mathrm{m}^{-1}\right.$ for mix $\mathrm{W}$ and $4 \mathrm{~mm} \cdot \mathrm{m}^{-1}$ for mix $\left.\mathrm{C}\right)$. As Murphy, it is possible to see that the wall formulation (mix W) always has a higher shrinkage than the coating formulation (mix C). Mix W having a higher W/B ratio and a higher amount of hemp, water mobilization for plant particles will therefore be greater, which may cause a shrinkage increasing.

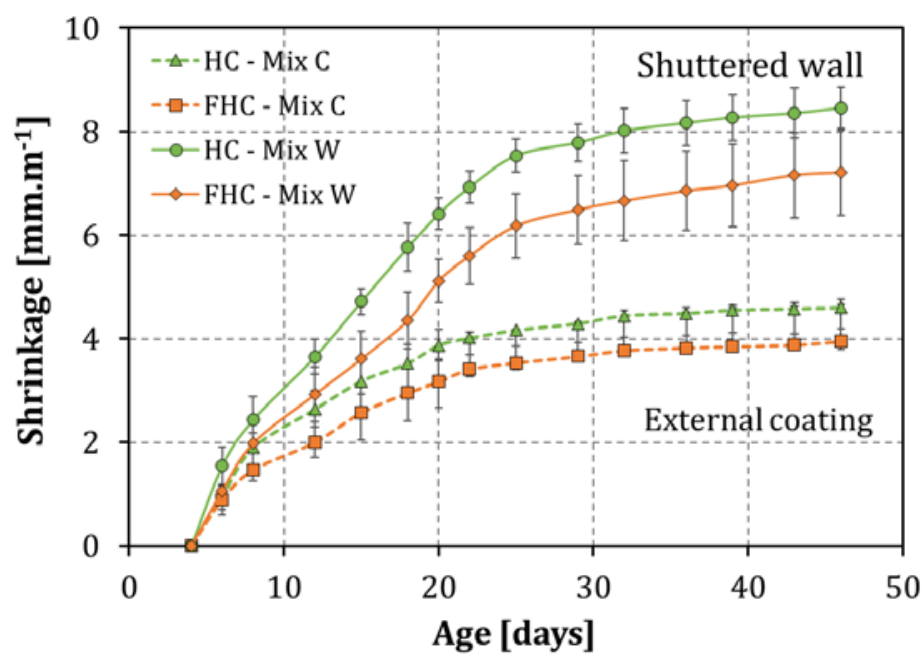

Fig. 14. Shrinkage measured for HC and FHC.

\subsection{Mechanical properties}

\subsubsection{Influence of compaction direction}

Hemp concrete has a different behavior depending on the direction of compaction during the casting process [16]. Conventionally, hemp concretes are compacted manually and are solicited 
alongside their compaction direction. The compressive force is thus directed perpendicular to the fiber orientation due to the implementation. Conversely, when the compression test is performed perpendicularly to the direction of compaction, hemp shiv particles (oriented compaction) are more stressed in their longitudinal direction. This is their direction of greater rigidity.

Only mix C (external coating) was tested in compression with a direction perpendicular to the compacting direction. Indeed, mix $\mathrm{C}$ is a mixture for an external rendering. For this mixture, hemp concrete is implemented by projection. For this implementation process, hemp concrete is compacted perpendicularly to the loading direction. For mixtures W and F (respectively shuttered walls and floor insulation) the loading direction is parallel to compaction. Finally, for the mix R which corresponds to roof insulation, the orientation is neither parallel nor perpendicular; it depends on the slope of the roof.

The curve obtained for the mix $\mathrm{C}$ with a parallel orientation was also plotted (Fig. 15). It can be noticed a ductile behavior for this material. There is no brittle fracture; the material has a large deformation capacity. A compression in the direction orthogonal to the compaction generates a greater elastic modulus and a higher compressive strength than compression carried out in parallel to compaction (Fig. 15). In other words, compression performed in parallel to the preferential orientation plane (longitudinal) of parallelepiped aggregates generates a higher stiffness than when stress is applied on these same particles perpendicularly to this plane. This observation may be related to the wood behavior, for which is commonly observed mechanical properties more than 10 times in the longitudinal direction of the rod. 


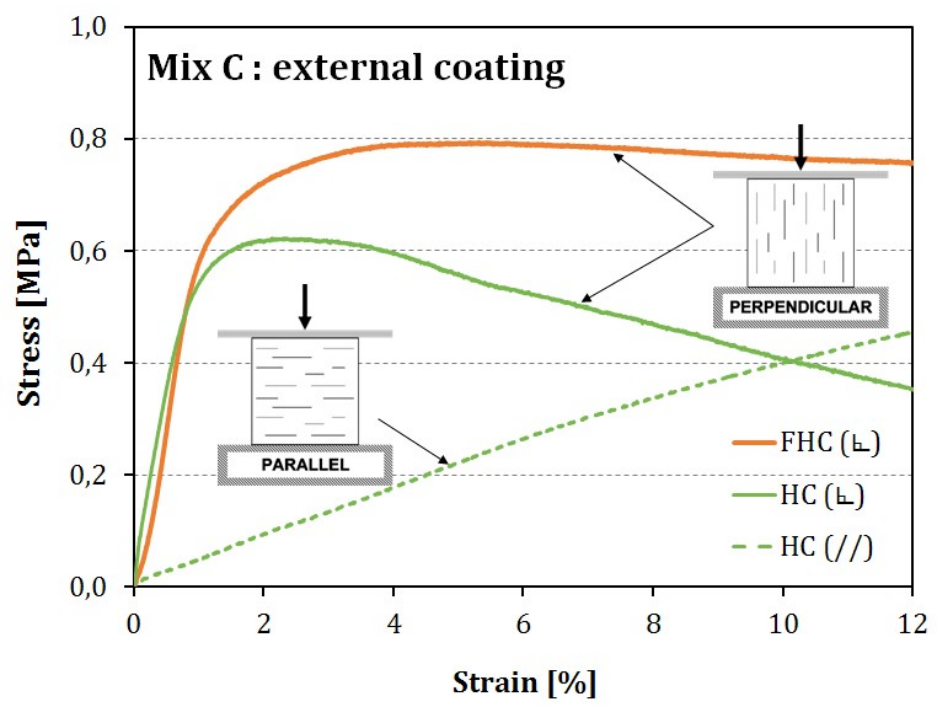

Fig. 15. Mechanical behavior of HC and FHC during a compressive test depending on the direction of compaction.

In perpendicular orientation, $\mathrm{HC}$ has initially a quasi-linear behavior up to the maximum stress of 403 about $0.63 \mathrm{MPa}$. Then, the material continues to be deformed but the stress decreases. For hemp 404 concrete with $10 \%$ flax fibers (FHC), the same behavior is observed. However, the maximum stress is $0.79 \mathrm{MPa}, 25 \%$ higher than HC. In addition, a different mechanical behavior is observed for FHC in large strains (above 4\% strain). Indeed, the stress remains high while continuing to be deformed. Indeed, the stress remains high while continuing to deform. For FHC, the stress is equal to $0.76 \mathrm{MPa}$ at $12 \%$ strain, while it is $0.36 \mathrm{MPa}$ for HC. Thus, flax fibers allow creating reinforcement in the composite material. They limit the cracks opening and slow the concrete failure. Fig. 16 shows a SEM image showing the typical interface between a flax fiber and a cementitious matrix [21]. 


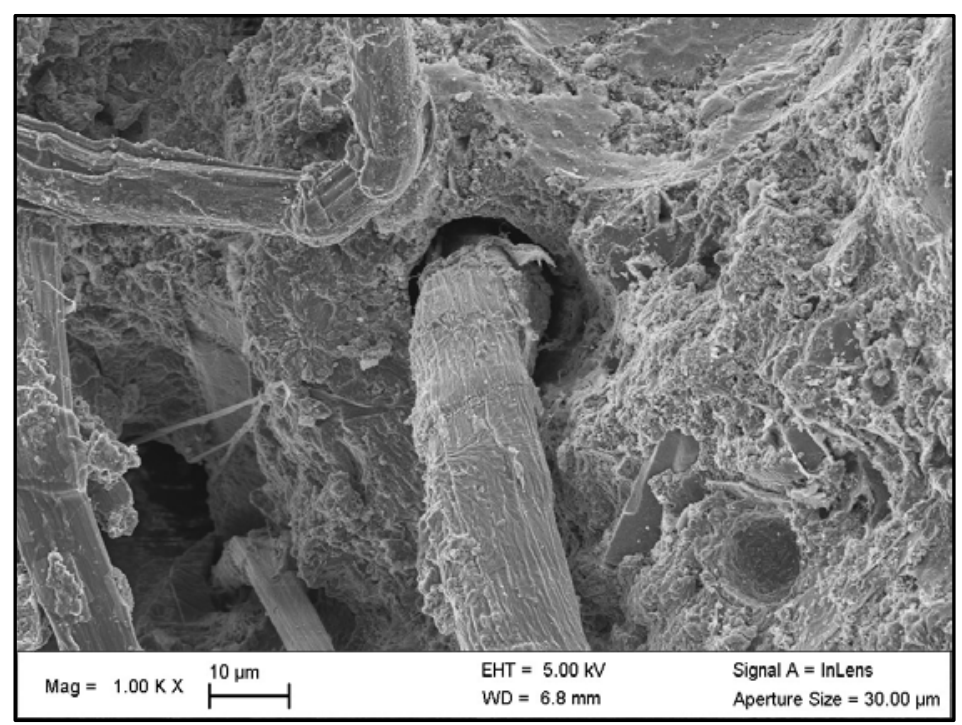

Fig. 16. SEM observation of a typical interface between a flax fiber and a cementitious matrix [21].

\subsubsection{Compressive strength at $5 \%$ strain in parallel orientation}

The compression test was carried out on all the mixtures for samples stressed in parallel to the compacting direction. As it can be seen in Fig. 15, hemp concrete has a quasi-linear behavior for a compression in parallel to the compacting direction. There is no maximum stress value; the resistance continues to increase until the end of the test, at $12 \%$ deformation. To compare the results between them, the resistance at $5 \%$ strain was defined as the acceptable maximum stress.

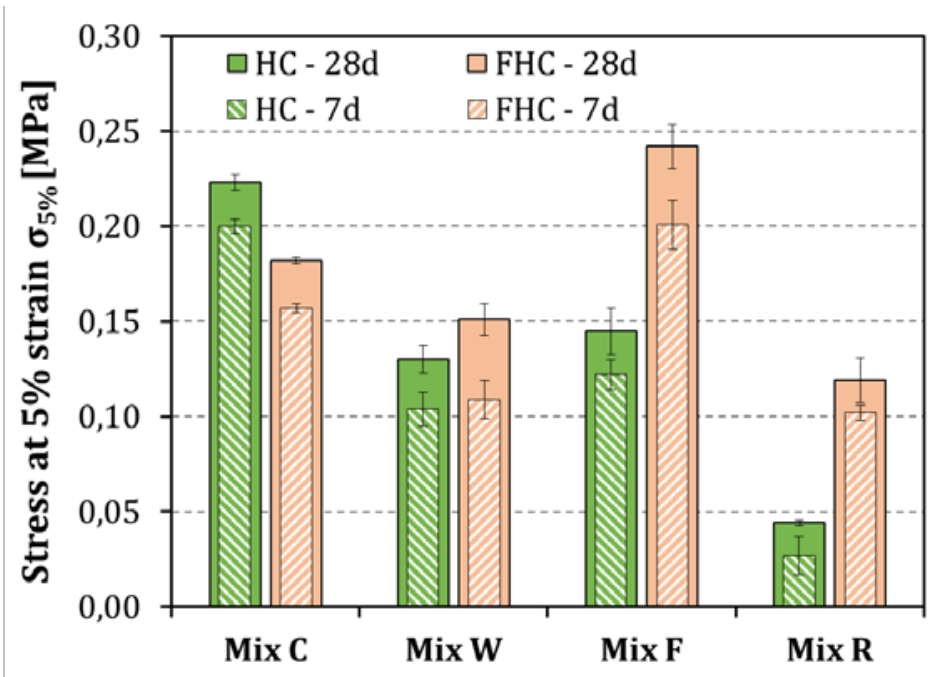


From Fig. 17, it can be seen that the incorporation of flax fibers into the concrete has a positive effect for mix W, F and R, respectively with an increase in resistance of $16 \%, 67 \%$ and $170 \%$ after 28 days curing. Only mix C, which has the lowest amount of hemp, has better resistance with HC; a decrease in strength of about $18 \%$ is observed for the hybrid hemp -flax composite.

As it can be seen in Fig. 18, there is a relationship between the effect of flax fibers on hemp concrete strength and the density. From these results, the resistance improvement of the composites would be due to the increased density of samples. Indeed, hemp-flax composite density has increased relative to standard hemp concretes. This increased density is related to an improvement of the compactness of the material, allowed by the incorporation of fibers into the mixture. Indeed, the fibers having a less porous structure and a very small diameter, they were able to fit into the intergranular voids of the hemp concrete.

In addition, as shown in Fig. 8, flax fibers absorb less water than hemp shives. Thus, the amount of water available for the binder is greater, which may limit the hydration and setting problems regularly observed with hemp concrete.

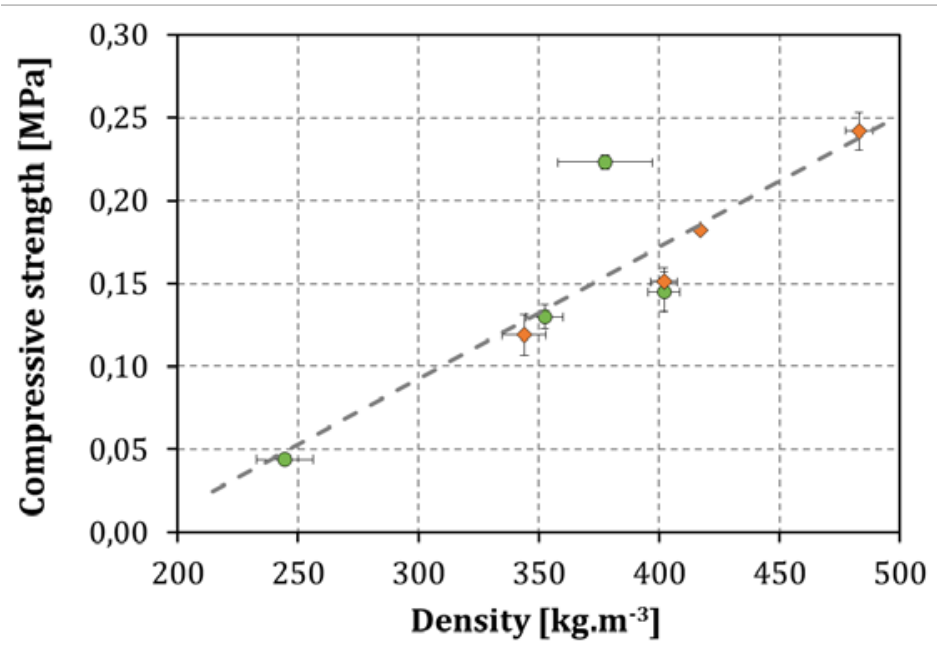

Fig. 18. Compressive strength (28 days) according to the density.

\subsection{Thermal conductivity}

The thermal conductivity of $\mathrm{HC}$ and FHC composites was measured in dry state (drying at $60^{\circ} \mathrm{C}$ in an oven for 48 hours). Fig. 19 presents the variation of thermal conductivity in function of density. The 
results show a linear relation between thermal conductivity and hempcrete density. This relationship has already been highlighted by several authors who have been interested in the thermal characteristics of hemp concrete $[8,18,19]$.

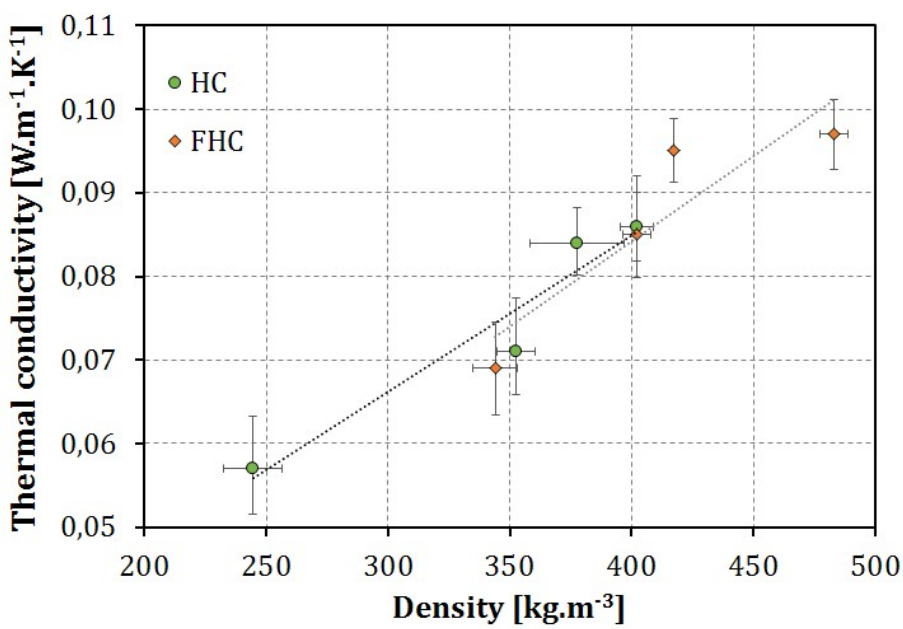

Fig. 19. Thermal conductivity of HC and FHC composites according to their density.

It seems that FHC mixes follows the same logic than HC composites for the thermal conductivity. For HC, the thermal conductivity varied between 0.057 and $0.086 \mathrm{~W} \cdot \mathrm{m}^{-1} \cdot \mathrm{K}^{-1}$. However, the thermal conductivity ranged between 0.069 to $0.097 \mathrm{~W} \cdot \mathrm{m}^{-1} \cdot \mathrm{K}^{-1}$ for $\mathrm{FHC}$ mixes. These higher thermal conductivity values are related to the higher density of the flax-hemp concrete formulations. However, all the values obtained for the thermal conductivity coefficient are still very low. Therefore, the FHC composites can also be considered as a building material with good thermal performances.

\section{Conclusion}

A new eco-friendly composite material for building construction has been developed by using hemp shiv and flax fibers as vegetable aggregates and a lime-based binder. To assess the performance of the composite material, various tests were performed on the composite material and on the conventional hemp concrete.

First, the water absorption test carried out on the plant aggregates showed the very high capacity for water absorption of hemp shives, almost $450 \%$ after 48 hours. Flax fibers had a water absorption about twice lower than that of hemp shiv (215\% after 48 hours). It was also shown that the water 
absorption of hemp shives and flax fibers follow a logarithmic law. The water absorption of plant aggregates is known to be problematic for agro-concretes. The lowest water absorption of flax fibers is thus an advantage to formulate bio-aggregate based concretes.

Then flax fibers have improved the mechanical behavior of hemp concrete on two different points. Firstly, the incorporation of the flax fibers has increased the ductility of the hemp concrete. Even in large deformations (above 5\%), the hybrid hemp-flax concrete retains its almost maximum compressive strength. Secondly, hybrid concrete has reached better compressive strength (at $5 \%$ strain) for the formulations intended for shuttered wall, floor insulation and roof insulation.

Concerning the capillary water absorption, a general trend due to the incorporation of flax fibers could not be observed. However, the hybrid composite appears to have a lower water absorption than hemp concrete mixtures containing a lower amount of vegetable particles (external rendering and floor insulation). A linear relationship between the coefficient of absorption and the capillary aggregates/paste ratio was observed with hemp concrete. This relation cannot however be observed for the hybrid hemp-flax composite. This could be explained by an increased complexity of the concrete porosity, and an increased tortuosity of the capillary networks.

The shrinkage of these two materials was also measured. Hemp-flax hybrid concretes showed a lower shrinkage of about $15 \%$ compared to conventional hemp concrete.

Finally, values obtained for the thermal conductivity coefficient are still very low. Therefore, hybrid composite may also be considered as an insulating construction material.

Thus, the incorporation of $10 \%$ flax fibers in hempcrete composition has allowed to make an insulating cementitious composite having improved performances compared to conventional hemp concrete. Further researches are needed to find the optimal replacement of hemp shiv by flax fibers. Furthermore, additional test is needed to be conducted in order to better quantify the porosity of these two materials. Finally, the fibers were usually used in concrete to increase their tensile strength. From the same perspective, it would be interesting to realize bending tests for this material. 


\section{Funding}

This research did not receive any specific grant from funding agencies in the public, commercial, or not-for-profit sectors.

\section{References}

[1] ADEME, Chiffres clés du bâtiment - Édition 2013, ADEME, 2013. http://www.ademe.fr/chiffrescles-batiment-edition-2013 (accessed October 22, 2014).

[2] M.-P. Boutin, C. Flamin, S. Quinton, G. Gosse, Etude des caractéristiques environnementales du chanvre par l'analyse de son cycle de vie, INRA - ADEME, 2006. http://agriculture.gouv.fr/IMG/pdf/chanvre_rapport_final_d235d.pdf.

[3] P. Bouloc, Le chanvre industriel - Production et utilisations, Éd. France agricole, Paris, 2006.

[4] S. Amziane, M. Sonebi, Overview on Biobased Building Material made with plant aggregate, RILEM Tech. Lett. 1 (2016) 31-38. doi:10.21809/rilemtechlett.2016.9.

[5] A.D. Tran Le, C. Maalouf, T.H. Mai, E. Wurtz, F. Collet, Transient hygrothermal behaviour of a hemp concrete building envelope, Energy Build. 42 (2010) 1797-1806. doi:10.1016/j.enbuild.2010.05.016.

[6] A. Evrard, A. De Herde, Hygrothermal performance of lime-hemp wall assemblies, J. Build. Phys. 34 (2010) 5-25. doi:10.1177/1744259109355730.

[7] P. Glé, E. Gourdon, L. Arnaud, Acoustical properties of materials made of vegetable particles with several scales of porosity, Appl. Acoust. $72 \quad$ (2011) 249-259. doi:10.1016/j.apacoust.2010.11.003.

[8] R. Walker, S. Pavía, Moisture transfer and thermal properties of hemp-lime concretes, Constr. Build. Mater. 64 (2014) 270-276. doi:10.1016/j.conbuildmat.2014.04.081. 
[9] S. Amziane, L. Arnaud, Bio-aggregate-based building materials - Applications to hemp concretes, Wiley-ISTE, London, 2013. http://onlinelibrary.wiley.com/book/10.1002/9781118576809 (accessed October 20, 2014).

[10] L. Arnaud, E. Gourlay, Experimental study of parameters influencing mechanical properties of hemp concretes, Constr. Build. Mater. 28 (2012) 50-56. doi:10.1016/j.conbuildmat.2011.07.052.

[11] Y. Diquélou, E. Gourlay, L. Arnaud, B. Kurek, Impact of hemp shiv on cement setting and hardening: Influence of the extracted components from the aggregates and study of the interfaces with the inorganic matrix, Cem. Concr. Compos. 55 (2015) 112-121. doi:10.1016/j.cemconcomp.2014.09.004.

[12] S. Elfordy, F. Lucas, F. Tancret, Y. Scudeller, L. Goudet, Mechanical and thermal properties of lime and hemp concrete ("hempcrete") manufactured by a projection process, Constr. Build. Mater. 22 (2008) 2116-2123. doi:10.1016/j.conbuildmat.2007.07.016.

[13] R. Walker, S. Pavia, R. Mitchell, Mechanical properties and durability of hemp-lime concretes, Constr. Build. Mater. 61 (2014) 340-348. doi:10.1016/j.conbuildmat.2014.02.065.

[14] M. Chabannes, E. Garcia-Diaz, L. Clerc, J.-C. Bénézet, Studying the hardening and mechanical performances of rice husk and hemp-based building materials cured under natural and accelerated carbonation, Constr. Build. Mater. $94 \quad$ (2015) 105-115. doi:10.1016/j.conbuildmat.2015.06.032.

[15] C. Niyigena, S. Amziane, A. Chateauneuf, L. Arnaud, L. Bessette, F. Collet, G. Escadeillas, C. Lanos, M. Lawrence, C. Magniont, S. Marceau, S. Pavia, U. Peter, V. Picandet, M. Sonebi, R. Walker, RRT3: statistical analysis of hemp concrete mechanical properties variability, in: Proc. 1st Int. Conf. BioBased Build. Mater., RILEM, Clermont-Ferrand, France, 2015: pp. 334-340.

[16] V. Nozahic, S. Amziane, G. Torrent, K. Saïdi, H. De Baynast, Design of green concrete made of plantderived aggregates and a pumice-lime binder, Cem. Concr. Compos. 34 (2012) 231-241. doi:10.1016/j.cemconcomp.2011.09.002. 
[17] T.-T. Nguyen, V. Picandet, S. Amziane, C. Baley, Influence of compactness and hemp hurd characteristics on the mechanical properties of lime and hemp concrete, Eur. J. Environ. Civ. Eng. 13 (2009) 1039-1050. doi:10.1080/19648189.2009.9693171.

[18] T.T. Nguyen, V. Picandet, P. Carre, T. Lecompte, S. Amziane, C. Baley, Effect of compaction on mechanical and thermal properties of hemp concrete, Eur. J. Environ. Civ. Eng. 14 (2010) 545560. doi:10.1080/19648189.2010.9693246.

[19] V. Cérézo, Propriétés mécaniques, thermiques et acoustiques d'un matériau à base de particules végétales : approche expérimentale et modélisation théorique, $\mathrm{PhD}$ thesis, Ecole Nationale des $\begin{array}{llll}\text { Travaux } & \text { Publics detat, } & \end{array}$ http://www.sudoc.abes.fr/DB=2.1//SRCH?IKT=12\&TRM=09460973X\&COOKIE=U10178,Klect eurweb,D2.1,E1288a28c-30e,I250,B341720009+,SY,A \9008+1,J,H2-26,,29,,34,,39,,44,,4950,,53-78,80-87,NLECTEUR+PSI,R79.141.14.118,FN (accessed April 5, 2015).

[20] K. Charlet, J.-P. Jernot, J. Breard, M. Gomina, Scattering of morphological and mechanical properties of flax fibres, Ind. Crops Prod. 32 (2010) 220-224. doi:10.1016/j.indcrop.2010.04.015.

[21] T. Le Hoang, M. Boutouil, F. Khadraoui, M. Gomina, Mechanical and microstructural characterization of flax fibre-reinforced cement composite, in: Proc. 11th Jpn.-Korea-Fr.-Can. Jt. Semin. Geoenvironmental Eng., Paralia, Caen, France, 2012: pp. 131-136. http://www.paralia.fr/editions_paralia_catalogue__872.htm.

[22] Construire en Chanvre, Règles professionnelles d'exécution d'ouvrages en bétons et mortiers de $\begin{array}{llll}\text { chanvre, } & \text { SEBTP, } & \text { SEBTP, } & \text { Paris, }\end{array}$ http://librairie.sebtp.com/product_book_info/livres-environnement-c-91_114/construire-enchanvre-regles-professionnellesexecution-edition-2012-p-297\#.VpKBOE-NqZk.

[23] S. Amziane, F. Collet, Round Robin Test for hemp shiv characterisation: Part 2, bulk density and particle size distribution, Springer Edition, Edited by S. Amziane, 2016. 
[24] S. Amziane, F. Collet, Round Robin Test for hemp shiv characterisation: Part 3, thermal conductivity, Springer Edition, Edited by S. Amziane, 2016.

[25] F. Collet, J. Chamoin, S. Pretot, C. Lanos, Comparison of the hygric behaviour of three hemp concretes, Energy Build. 62 (2013) 294-303. doi:10.1016/j.enbuild.2013.03.010.

[26] C. Igathinathane, L.O. Pordesimo, E.P. Columbus, W.D. Batchelor, S. Sokhansanj, Sieveless particle size distribution analysis of particulate materials through computer vision, Comput. Electron. Agric. 66 (2009) 147-158. doi:10.1016/j.compag.2009.01.005.

[27] EN 933-2, Tests for geometrical properties of aggregates - Determination of particle size distribution, (1996).

[28] S. Chafei, F. Khadraoui, M. Boutouil, M. Gomina, Effect of flax fibers treatments on the rheological and the mechanical behavior of a cement composite, Constr. Build. Mater. 79 (2015) 229-235. doi:10.1016/j.conbuildmat.2014.12.091

[29] M. Chabannes, V. Nozahic, S. Amziane, Design and multi-physical properties of a new insulating concrete using sunflower stem aggregates and eco-friendly binders, Mater. Struct. (2014). doi:10.1617/s11527-014-0276-9.

[30] V. Nozahic, S. Amziane, Influence of sunflower aggregates surface treatments on physical properties and adhesion with a mineral binder, Compos. Part Appl. Sci. Manuf. 43 (2012) 18371849. doi:10.1016/j.compositesa.2012.07.011.

[31] S. Amziane, F. Collet, Round Robin Test for hemp shiv characterisation: Part 1, evaluation of initial water content and water absorption, Springer Edition, Edited by S. Amziane, 2016.

[32] NF P15-433, Méthodes d'essais des ciments - Détermination du retrait et du gonflement, (1994).

[33] EN ISO 8894, Refractory materials - Determination of thermal conductivity - Hot-wire method, (2010). 
[34] A. Franco, An apparatus for the routine measurement of thermal conductivity of materials for building application based on a transient hot-wire method, Appl. Therm. Eng. 27 (2007) 24952504. doi:10.1016/j.applthermaleng.2007.02.008.

[35] M. Chabannes, J.-C. Bénézet, L. Clerc, E. Garcia-Diaz, Use of raw rice husk as natural aggregate in a lightweight insulating concrete: An innovative application, Constr. Build. Mater. 70 (2014) 428438. doi:10.1016/j.conbuildmat.2014.07.025.

[36] V. Nozahic, Vers une nouvelle démarche de conception des bétons de végétaux lignocellulosiques basée sur la compréhension et l'amélioration de l'interface liant/végétal - Application à des granulats de chenevotte et de tige de tournesol associés à un liant ponce/chaux, PhD thesis, Université Blaise Pascal - Clermont-Ferrand II, 2012. http://tel.archives-ouvertes.fr/tel00822142.

[37] M. Sonebi, S. Wana, S. Amziane, J. Khatib, Investigation of the mechanical performance and weathering of hemp concrete, in: Proc. 1st Int. Conf. Bio-Based Build. Mater., RILEM, ClermontFerrand, France, 2015: pp. 416-421.

[38] C. Magniont, Contribution à la formulation et à la caractérisation d'un écomatériau de construction à base d'agroressources, PhD thesis, Université Paul Sabatier - Toulouse III, 2011. http://thesesups.ups-tlse.fr/980/.

[39] F. Murphy, R. Walker, S. Pavia, An assessment of some physical properties of lime-hemp concrete, in: Ni Nuallain, Walsh, West, Cannon, Caprani, McCabe, University College Cork, Ireland, 2010. http://www.tara.tcd.ie/handle/2262/57402 (accessed January 12, 2016).

[40] A. Kashtanjeva, M. Sonebi, S. Amziane, Investigation of the mechanical performance and drying shrinkage of hemp concrete, in: Proc. 1st Int. Conf. Bio-Based Build. Mater., RILEM, ClermontFerrand, France, 2015: pp. 309-315. 